\title{
The Role of Sustainability Orientation in Outsourcing: Antecedents, Practices, and Outcomes
}

\author{
Shuting $\mathrm{Li}^{1}$, Sam Okoroafo ${ }^{1} \&$ Bashar Gammoh ${ }^{1}$ \\ ${ }^{1}$ College of Business and Innovation, The University of Toledo, Toledo, Ohio, USA \\ Correspondence: Sam Okoroafo, College of Business and Innovation, University of Toledo, Toledo, Ohio 43606, \\ USA. Tel: 1-419-530-4396. E-mail: sam.okoroafo@utoledo.edu
}

Received: May 22, 2014

Accepted: June 13, 2014 Online Published: August 29, 2014

doi:10.5539/jms.v4n3p27

URL: http://dx.doi.org/10.5539/jms.v4n3p27

\begin{abstract}
With growing awareness of environmental issues and firm social responsibilities, outsourcing firms increasingly recognize the need to be sustainability-oriented as they pursue competitiveness in the global market. However, firms are not doing this purely for altruist reasons as they still have to make a profit and account to shareholders. Therefore thispaper investigates the antecedents that push firms that adopt outsourcing initiatives to be sustainability-oriented. The authors develop a model that identifies the antecedents, goals, practices, and outcomes associated with the sustainability-outsourcing linkage. The model starts by identifying four antecedents (regulations, supply chain demand, firm reputation, and marketplace requirements) that cause of sustainability orientation in a firm. Then, internal (i.e., product design) and external (i.e., supplier management) practices thatfirms may adopt in order to cope with their sustainability goals are introduced. Finally, the model evaluates the impact of these practices on their outsourcing performance from the triple bottom line perspective. So this is a conceptual paper that sheds light on the role of sustainability orientation in outsourcing firms' performance, and calls for more research attention on sustainable outsourcing.
\end{abstract}

Keywords: sustainability, outsourcing, practices, performance, regulations

\section{Introduction}

As the business competition grows increasingly global and complex, firms have realized that it is no longer possible for them to gain and maintain competitiveness in the global market on their own. So involving other firms via outsourcing has been a useful strategic tool to leverage globally dispersed resources as it provides advantages in cost, capability, and many other aspects compared to going it alone (i.e., in-sourcing).Thus firms can focus their limited resources on their core competency and potentially be more efficient and effective in the global market (Kannan \& Tan, 2002; Lankford \& Parsa, 1999). At the same time, the increasingly heavy environmental pressures have caused the business environment to change in many ways (Zhu, Sarkis, \& Lai, 2012). Firms are facing growing stringent environmental regulations, and customer demand for environmentally sound products. They'll need to pursue sustainability in order to win a good reputation as socially responsible. Also, marketplace requirements can be acatalyst as well when they try to enter a market with high environmental requirements such as Europe (Defee, Esper, \& Mollenkopf, 2009).

While sustainability has become a major challenge for firms, the goal of pursuing sustainability cannot be achieved by merely one firm as the firms' performance will be always affected by other entities in the supply chain. When firms outsource some of their products or services from outside entities, it becomes even more critical for them to not only be sustainable oriented internally, but also to transfer this orientation to their upstream and downstream business partners. That way the whole supply chain can be sustainable, and the mutually reinforcing goal of sustainability can be fulfilled. This shift of environmental and social responsibility for outsourcing firms is predicted to be beneficial for those who proactively adopt the sustainability mindset in outsourcing, and challenging for those who do not (Brown, 2008). However, despite the importance of pursuing sustainability in outsourcing, research in this area is still scarce with a few exceptions (Babin \& Nicholson, 2009; Dou \& Sarkis, 2010). Only recently have scholars started to call for more research on the sustainability-sourcing tie-in, as the traditional focus has been mainly in the IT area (Jain \& Khurana, 2013). This paper answers that call by shedding some light on the role of sustainability in outsourcing practices through identifying, the antecedents that cause firms to be sustainability oriented; the internal and external practices firms may adopt in 
order to cope with the changes of their business goals; and the impact of these practices on their outsourcing performance.

\section{Literature Review}

\subsection{Outsourcing}

Outsourcing can be defined as procurement of products or service from any firm outside of your own entity (Gray, Roth, \& Leiblein, 2011; Grossman \& Elhanan, 2005; Lankford \& Parsa, 1999). The main aim of outsourcing is to make the business or organization more competitive by staying focused on their core competencies. So the goal of outsourcing in the supply chain is to derive a competitive advantage (Kroes \& Ghosh, 2010). According to the transaction cost theory (Williamson, 1979, 2008) and the resource-based view (Hunt \& Davis, 2008; Wernerfelt, 1984), firms choose to outsource when they see there is an advantage both in cost and capability compare to in-sourcing.

Some studies have identified a few motivations of firms adopting outsourcing in their supply chain. They include reducing cost and improving firm's financial performance, allowing firms to focus on core competencies, and being able to obtain quality or technology from outside that would be too expensive or hard for them to replicate internally (Kumar, Medina, \& Nelson, 2009; Lacity, Khan, \& Willcocks, 2009). Other studies have mentioned simplifying operations and improving efficiency, allowing quick response to environmental changes, improving product quality, acquiring new capabilities, and bringing fundamental strategic and structural change (Holcomb \& Hitt, 2007; Kumar, Medina, \& Nelson, 2009; Lacity, Khan, \& Willcocks, 2009; Lankford \& Parsa, 1999; Zhang \& Huang, 2012).

In the book "The Black Book of Outsourcing 2007 Green Outsourcers Report", Brown \& Wilson (2007) identified 5 industries that are most likely to adopt green outsourcing: information technology (94.4\%), Facilities management outsourcing $(92.2 \%)$, Document process outsourcing $(79.8 \%)$, Business process outsourcing (79.5\%), and Supply chain, transportation \& Logistics (76.6\%). They also have provided 12 steps to develop a green outsourcing initiative. They are: commit, designate, communicate, assess, set goals, learn, review, put it in motion, phase in, evaluate, market \& get the word out, and monitor. Other literature has also documented that due to the scale of environmental and natural resources problem caused by lack of concern for the environment, environmental awareness is becoming more important to the society, government, industry, and everyone, and there is a strong demand for sustainability in outsourcing (Elkington, 1994; Facanha \& Horvath, 2005).

\subsection{Sustainability}

Sustainable development was first advocated by former Norwegian Prime Minister Gro Harlem Brundtland while she was serving as the Chair of the World Commission on Environment and Development in 1987. Ever since then, sustainability or environmental issues have become a concern for many countries, among which European Union (EU) is regarded to have the most extensive environmental regulations. ISO14001 is one of those regulations. ISO14001 is management system standard established by the International Organization for Standardization (ISO) to formalize strategic approaches to environmental management. Klassen \& Vachon (2003) found that ISO14001 certification is significantly related to more extensive environmental investment.

Sustainability means to "meet the needs of the present without compromising the ability of future generations to meet their own needs" (Brundtland, 1987). There are different views toward sustainability. Some may suggest that it means to maintain output to match the growing demands; some may emphasize the importance of maintaining a desirable way of life in the future; and others may focus on the ecological balance. A broad view of sustainability incorporates all of the above views and suggests that sustainability is to interact with the environment in such a way that the future generations will not be disadvantaged (Biddle, 2011), and triple bottom line approach, which captures the performance from dimensions of economic, environmental and social helps to operationalize the sustainability (Seuring \& Müller, 2008). It suggests that firms "should operate in ways that ensures long-term economic performance by avoiding short-term behavior that is socially detrimental or environmentally wasteful" (Porter \& Kramer, 2006, p. 82).

Based on literature review, Carter \& Rogers (2008) define sustainable supply chain management as "the strategic, transparent integration and achievement of an organization's social, environmental, and economic goals in the systemic coordination of key inter-organizational business processes for improving the long-term economic performance of the individual company and its supply chains"(p. 368). Another literature review paper Seuring \& Müller (2008) define sustainable supply chain management "as the management of material, information and capital flows as well as cooperation among companies along the supply chain while taking goals from all three dimensions of sustainable development, i.e., economic, environmental, and social, into account"(p. 1700)The 
common thread of the two definitions lies in the triple bottom line perspective of achieving goals from three dimensions: economic, environment, and social.

Much literature attention has focused on the importance and benefits of sustainability. Lubin and Esty (2010) argue that more and more executives know that how they respond to sustainability could greatly affect the competitiveness or even the survival of their firms.Hollos, Blome, \& Foerstl (2012) report that firms pursuing sustainability experience competitive advantages.

With regards to the implementation of sustainability, Elkington (1994) advocates the need for sustainable development due to the scale of the environmental and natural resource problems, and suggested "win-win-win" strategies that benefit the company, its customers, and the environment. Bowen, Cousins, Lamming, \& Farukt (2001) suggest several things firms could do, including to evaluate suppliers' environmental performance by providing an environmental assessment questionnaire to the suppliers, rank suppliers on their environmental performance, award suppliers for their improvement in environmental performance, and even require suppliers to have an environmental management system. As a result of supplier selection based on environmental, the supplier that has a higher environmental score should be selected and maintained as part of the supply base. Zhu et al. (2012) divide firms' practices into internal and external, and suggest that in implementing green (sustainable) supply chain management, firms need to integrate internal practices (functional coordination) with external practices (such as supplier and customer cooperation) to fully realize the performance potentials. Ehrenfeld talked in the book "Oxford Handbook of Business and The Natural Environment" that firms can pursue sustainability by following "one of greening, eco-efficiency, triple bottom line, or any similar framework that is built around the reduction of sustainability, or it can adopt sustainability strategies designed to produce flourishing" (Bansal \& Hoffman, 2012, p. 613). Min \& Galle (1997) suggest that pursuing sustainability should be more than simply avoiding violations of environmental status. Firms need to embed environmental goals within their long-term strategies.

Literature has also explored the hinderingand supporting factors of pursuing sustainability. Min \& Galle (1997) state that "sustainability may result in increased material cost and limited qualified supplier because of the need for non-traditional materials and parts", and the "most serious obstacles are all based on costs and revenues: high cost of environmental programs, uneconomical recycling, and uneconomical reuse" (Min \& Galle, 1997, p. 15). Ageron, Gunasekaran \& Spalanzani (2012) mention that there are multiple sources of resistance againstsustainability, including "top management, financial issues, location, system capacity, culture, type of business, supply chain network configuration, costs, performance objectives, human resources, and knowledge management" (p. 172). Seuring \& Müller (2008) state that higher costs, coordination complexity/effort and insufficient/missing communication in the supply chain are the three main barriers. And company-overlapping communication, management systems, monitoring, evaluation, reporting, sanctions, training, education of purchasing employees and suppliers, and integration into the corporate policy are the supporting factors for sustainable supply chain management they found in their literature review on 191 papers during time period of 1994 to 2007.

After conducting a literature review on sustainable supply chain management, Seuring \& Müller (2008) conclude that sustainability should cover three dimensions: social, economic and environment. However, most research mainly focuses on green/environmental issues; research on social aspects and the integration of the three dimensions of sustainability is still lacking.

A review of the above literature suggests the following conclusions. The importance and necessity of sustainability orientation are well established in the literature and warrants continued research. The demand for sustainability in outsourcing is presented in the literature, however, the research that answers to this demand is lacking. Especially, there is an absence of research clearly linking the antecedents, goals, practices, and outcome of sustainability orientation in outsourcing practice. Thus, this research investigates the role of sustainability orientation in outsourcing by examining its antecedents, practices, and corresponding outcomes.

\section{Antecedents of Sustainability Orientation}

Based on Carter \& Rogers (2008) and Seuring \& Müller (2008)'s definition for sustainable supply chain management, we define sustainable outsourcing as the strategic integration and achievement of a firm's social, environmental, and economic goals in its sourcing to a third party entity. We investigate the antecedents that push firms to pursue sustainability orientation, the practices of the sustainability orientation, and its outcome using the triple bottom line approach to measure the economic, environmental and social performance of outsourcing. 
Firms are increasingly facing growing stringent environmental regulations and social responsibilities, customer demand for environmentally sound products, need to win good reputation as socially responsible, and marketplace requirement as well (Ageron et al., 2012; Biddle, 2011; Seuring \& Müller, 2008). All those internal and external factors (see, Figure 1) push firms to pursue sustainability in their outsourcing practice. Below we will discuss the different drivers of firms' sustainability orientation.

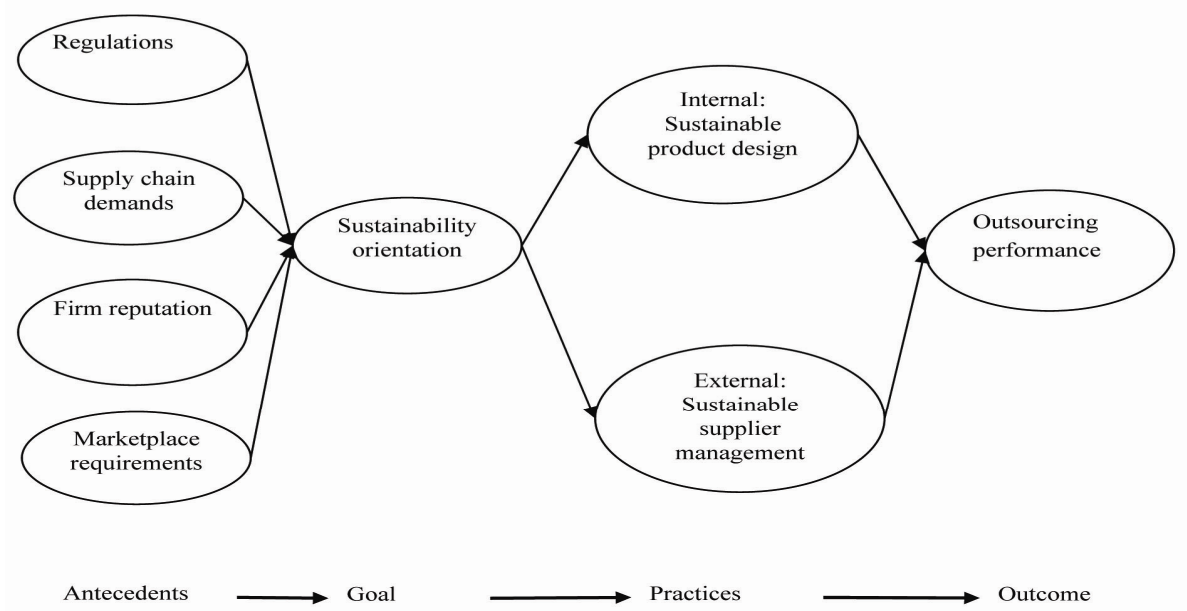

Figure 1. Research framework

\subsection{Regulations}

Environmental regulations in domestic country are one of the reasons for some firms to outsource. It may be that some pollution intensive parts of their production are not allowed for production in their own places due to the stringent domestic environmental regulations, so they outsource those parts from countries where the environmental regulations are not so strict or still allow the production of these products (Cole, Elliott, \& Okubo, 2011). In the past decade, research attention has been paid to this phenomenon, which is called Pollution Haven Hypothesis (PHH). PHH states that environmental regulations will move pollution-intensive industries or productions to less regulated countries. Scholars argue that outsourcing brought job opportunity and economic benefits to developing countries. However, those countries sacrificed environmentally, and became pollution havens (Cole, Elliott, \& Fredriksson, 2006; Ederington, Levinson, \& Minier, 2005; Eskeland \& Harrison, 2003). Scholars have foreseen that the pressure on the environment would increasingly grow as the economic and industrial growth continue (Lotspeich \& Chen, 1997; Smil, 1993).

Among the many pressures that firms encounter in their supply chain regarding sustainability requirements, regulations play a major role as they obligate firms to adopt certain practices in order to be qualified to 'play in the game'. If firms do not want to or fail to follow the regulation, they would have to pay penalties and not be allowed to continue what they have been doing (Ageron et al., 2012).

\subsection{Supply Chain Demand}

Literature has shown that buying firms have an important effect on the performance of their supply base in terms of quality, new production development and cost. Yet Klassen \& Vachon (2003) state that theirimpact can extend beyond traditional manufacturing performance dimensions to environmental management. In their research, Klassen and Vachon found that when buying firms adopt formal evaluation of the environmental performance of their suppliers, they are more likely to see positive changes in how suppliers regard environmental issues.

As early as in the 1990s last century, firms started to face pressure from their buying firms in regards to their environmental performance.Brown \& Wilson (2007) states that "organizations in North America and Europe plan to continue their outsourcing initiatives while cautiously shifting functional responsibility for corporate environmental concerns to the supplier, but at the same time, most buyers are demanding that their suppliers implement comprehensive green initiatives to assure compliance"(p. 6).Elkington (1994) documented Scott Paper as one of the first firms to review their suppliers on their environmental performance regarding to air, water, land releases, energy consumption, and energy sources. Based on the scores it got from the questionnaires 
they sent out to their suppliers to ask for those figures, Scott Paper dropped the worst $10 \%$ of their suppliers. The Ford Motor example mentioned earlier is also a case illustrating that customer demand is having impacts on their suppliers to pursue sustainability in response to their requirements. Many other firms such as Nike, Adidas, and Sony also have sustainable requirements for their suppliers (Ageron et al., 2012).Brown (2008) predicts that the outsourcing suppliers will be pressured to produce green credentials and adopt sustainable initiatives in order to meet client demand and be the order qualifiers, and then eventually become the order winners. Seuring \& Müller (2008) document that firms are also required by the focal firms to perform according to the environmental and social standards (i.e., ISO14001 and SA8000). In 2007, over 43\% first time outsourcing clients included environmental factors in their supplier selection processes, and $18 \%$ added contractual goals for their outsourcers (Brown \& Wilson, 2007).

\subsection{Firm Reputation}

Firms, especially large firms are constantly under the watchful public eyes. They have significant impacts on social relations and are held responsible for their products as well as related environmental and social issues, such as the use of child labor, insufficient safety regulations, wages below the legally guaranteed minimum amount, suppression of labor unions or their formation, discrimination and unreasonable working hours(Beske, Koplin, \& Seuring, 2008).

As the society increasingly favors more firms that are known for making extra efforts to be environmental friendly and socially responsible, firms gain good reputation if they go beyond the required standards to reduce waste and damage to the environment and be considerate toward their social responsibilities (Ageron et al., 2012). A good reputation improves a firm's image, strengthens its brand, enliven morale, and even raises the value of its stock (Porter \& Kramer, 2006). On the contrary,if firms go against what the society desires, they would suffer from the public boycott of their products. Nike's sweatshop scandal is one of the examples. When it was reported that Nike had been using child labor in Indonesia, it had a severe public relation problem that could damage the good name of the firm, which is the most important strength of the firm. Porter \& Kramer (2006) suggest that for stigmatized industries, firms may pursue sustainability orientation as a form of insurance to temper public criticism in crisis by its reputation for social consciousness.

\subsection{Marketplace Requirement}

Requirements from the market is another pressure for firms to be sustainability oriented. At the end of the day, thecustomer is the determinants of a firm's success or failure: the firm that wins the customer wins the market. So firms, especially big firms are always looking at the demand of their current customers (Bower \& Christensen, 1995). As consumers become more aware of the environmental damages and want to adopt an environmental friendly lifestyle, they look for green products and firms that adopting green strategies in their manufacturing process (Ageron et al., 2012).Seuring \& Müller (2008) mention that besides the pressure from social groups, firms may be more concerned with the boycott of their products from individual customers due to the report of environmental or social problems in their supply chain. Thus, customer requirements are also one of the reasons that firms pursue sustainability.

\section{Sustainability-Oriented Practices}

In order to pursue sustainability in outsourcing, there are many practices outsourcing firms may adopt. Firms have to more cautiously deal with issues like energy consumption, waste disposal, recycling, alternative energies, environmentally preferable products and service, and the like (Brown \& Wilson, 2007). Generally speaking, those practices could mainly be divided into two aspects: internal practices and external practices (Seuring \& Müller, 2008). Internal practices focus more on functional coordination, such as product design and risk management. External practices are network cooperation with customers and supplier development. We suggest that internally firms should devote themselves to sustainable product development, and externally firms should conduct sustainable oriented supplier management in accordance with their sustainability goals.

\subsection{Sustainable Product Design}

In the earlier years, when some developing countries such as China and India had more forgiving environmental regulations compared with developed countries, firms used to dump the production or outsource those products that were not allowed for production in their own countries to those so called "pollution haven" countries (Cole et al., 2006). However, now as the environmental problems become more severe in those developing countries, taking China as an example, the bar of environmental regulation has been rising in those countries as well, which made it more difficult to find the "pollution haven". If firms need highly environmentally unfriend products, they will have problems finding an outsourcing supplier and outsourcing destination. As firms adopt a sustainability 
orientation, they need to redesign their products according to the general environmental and social regulations, so that they can be really sustainable instead of shifting the unsustainable part to their upstream suppliers.

Sustainable products refer to products that have or aimed at an improved economic, environmental and social quality in accordance with the goal of sustainability. It aims to gain profit without compromising the environmental and social responsibilities. The goal is to meet customer's demand for environmental and social performance and gain competitive advantage in the market (Seuring \& Müller, 2008).Instead of outsourcing the environmentally harmful products to other countries, firms may want to redesign their product with materials that do not product much harm to the environment, with less energies consumption, or with alternative energies that will not deplete the existing critical energies. Firms may also keep in mind the closed loop supply chain to recycle the product after being consumed.Even though it seems to be more expensive to make products with higher environmental and social standards, in the long-run, the sustainability orientation would become firms' competitive advantage, thus would also lead to higher economic performance.As firms adopt sustainability oriented product design, they always keep environmental and social regulations in mind. Therefore, we expect them to have higher performance on environmental and social aspects as compared to those without sustainability orientation.

\subsection{Sustainable Supplier Management}

The goal of pursuing sustainability cannot be achieved merelyby one firm as the eventual outcome affects by all entities in the supply chain. Firms' sustainability is demonstrated by its supplier (Hsu \& Hu, 2009). Supplier selection and supplier development are two strategic tools that firms can use to improve their economic, environmental and social performance (Carter \& Easton, 2011). Firms used to select suppliers based on their economic performance, such as product quality, price, delivery speed and so forth. However, with sustainability orientation, firms can no longer focus only on those financial terms in evaluating suppliers; they need to adopt sustainable criteria of looking at supplier's economic, environmental and social performance in selecting and developing their suppliers in order to achieve their sustainable orientation (Amindoust, Ahmed, Saghafinia, \& Bahreininejad, 2012; Lee, Kang, Hsu, \& Hung, 2009). As Bowen et al. (2001) suggest, to better implement sustainability orientation, there are several things firms could do with their supplier management. Firms could evaluate suppliers' environmental performance by providing an environmental assessment questionnaire to the suppliers, rank suppliers on their environmental performance, award suppliers for their improvement in environmental performance, and even require suppliers to have an environmental management system. As a result of supplier selection based on environmental, the supplier that has a higher environmental score should be selected and maintained as part of the supply base. Seuring \& Müller (2008) suggest to increase communication between suppliers and the focal firm, communicate criteria to suppliers, conduct supplier evaluation and supplier development in order to achieve sustainability in the supply chain.

When the buying firms' goal of pursuing sustainability is communicated to and accepted by the suppliers, it is more likely that the suppliers would be collaborative in the outsourcing process. Supplier management includes supplier selection, evaluation and development (Kannan \& Tan, 2002). Suppliers are selected based on buying firm's requirements for product quality, price, service, delivery, technology, and especially sustainability to achieve buying firm's competitive advantages. After selection, evaluation is needed to make sure suppliers do meet buying firm's requirements, and perform at a satisfying level. Supplier selection is usually a time consuming and expensive process. Instead of changing supplier from time to time, buying firm may want to have stable suppliers to reduce cost and have an efficient purchasing process. In order to do so, buying firms need to develop suppliers for long-term cooperation. In order to be sustainability oriented, firms not only keep all the environmental and social regulations on their own, but also put them in the supplier selection criteria and use them to evaluate suppliers' performance.

As a result, we expect their outsourcing performance in terms of environmental and social aspects would be higher compared to those without being sustainability oriented. The literature has shown that supplier management has a positive impact on supplier performance and firm performance (Paulraj, 2011; Tracey \& Tan, 2001; Vonderembse \& Tracey, 1999). So we expect that sustainability oriented supplier management would be positively associated with firm's economic outsourcing performance.

\section{Discussion and Conclusions}

Sustainability is not new in today's industries. More and more firms participate in the pursuit of sustainability and see sustainability as a competitive advantage of the firm. Many firms require their suppliers to have ISO14001 certification, and make it as one of the criteria for supplier selection. For example, since 2003, Ford Motor had required even its US suppliers to have ISO14001, and this affected more than 5,000 of their existing 
collaborators (Ageron et al., 2012). In order to be qualified as a sustainable supplier, firms that provide outsourcing service may want to obtain the ISO 14001 certification by adapting their working process to the ISO 14001 requirements. In terms of social standards, SA8000 (SA stands for social accountability) is an international standard used for improving working conditions. SA8000 is based on the principles of 13 international human rights conerntions, and is a tool for helping apply these norms to practical worklife situations (Beske et al., 2008; Social Accountability International).

While sustainability is equally important, if not more important, for firms that adopt outsourcing as their strategic tool to gain capabilities, research attention in this area is scarce. This paper hasshed light on the role of sustainability orientation in firm's outsourcing performance through providing a framework that captures the antecedents, practices and outcomes of sustainability orientation, and calls for more research attention on sustainable outsourcing. Four antecedents that push firms to be sustainability oriented are identified (regulations, supply chain demands, firm reputation and marketplace requirements). Two internal and external practices that could help firms to achieve their goal of being sustainable are suggested. Instead of outsourcingthe non-sustainable products to other countries, firms could adopt sustainable product design to meet their sustainability orientation so that not only the firm alone, but the whole supply chain would become sustainable. At the same time, it is also critical for firms to have sustainable supplier management, to select suppliers with sustainable standards, assess suppliers' performance using the preset standards, and develop the suppliers to share the common goal of sustainability orientation.

In the real world, we have seen firms adopting those two practices in pursuing their sustainability orientation. $P \& G$ has dedicated itself to pursuing sustainability with innovative sustainable product design. To reduce the environmental impact of their products, $P \& G$ uses life cycle analysis to understand where the biggest impact exists so that they can focus their innovation on that particular issue. They try to develop sustainable products that will delight customers without trade-offs in price or performance. In 2010, P\&Glaunched a sustainability scorecard and rating process to assess suppliers' performance on water use, waste management and greenhouse gas emissions. Since 2009, Walmart has worked with some of their largest competitors on The Sustainability Consortium (TSC) to engage their suppliers and better understand the products for product sustainability. They used the TSC to develop an index for six product categories, which they used to create category scorecards for supplier performance evaluation.

This paper sheds light on sustainability in outsourcing, and calls for more research attention in this area, such as supplier management, which is an important part of outsourcing. In the area of supplier management, it would be interesting to investigate what are the indicators of selecting supplier with sustainability orientation, and if no current supplier meets the standards for sustainability, how to develop those suppliers to be sustainable-oriented. It would also be meaningful to study how capability emerges and diffuses in sustainable outsourcing.

\section{References}

Ageron, B., Gunasekaran, A., \& Spalanzani, A. (2012). Sustainable supply management: An empirical study. $\begin{array}{lllll}\text { International Journal of Production } & \text { Economics, } & 140(1), & 168-182 .\end{array}$ http://dx.doi.org/10.1016/j.ijpe.2011.04.007

Amindoust, A., Ahmed, S., Saghafinia, A., \& Bahreininejad, A. (2012). Sustainable supplier selection: A ranking model based on fuzzy inference system. Applied Soft Computing, 12(6), 1668-1677. http://dx.doi.org/ 10.1016/j.asoc.2012.01.023

Babin, R., \& Nicholson, B. (2009). Corporate social and environmental responsibility and global IT outsourcing. MIS Quarterly Executive, 8(4), 203-212.

Bansal, P., \& Hoffman, A. J. (2012). The Oxford handbook of business and the natural environment. Oxford University Press.

Beske, P., Koplin, J., \& Seuring, S. (2008). The use of environmental and social standards by German first-tier suppliers of the Volkswagen AG. Corporate Social Responsibility and Environmental Management, 15(2), 63-75. http://dx.doi.org/10.1002/csr.136

Biddle, I. (2011). Operations Management For A Sustainable Future. BusiDate, 19(1), 2-5.

Bowen, F. E., Cousins, P. D., Lamming, R. C., \& Farukt, A. C. (2001). The role of supply management capabilities in green supply. Production and Operations Management, 10(2), 174-189. http://dx.doi.org/10.1111/j.1937-5956.2001.tb00077.x 
Bower, J. L., \& Christensen, C. M. (1995). Disruptive Technologies: Catching the Wave. Harvard business review, 73(1), 43-53.

Brown, D. (2008). It is good to be green: environmentally friendly credentials are influencing business outsourcing decisions. Strategic Outsourcing: An International Journal, 1(1), 87-95. http://dx.doi.org/10.1108/17538290810857501

Brown, D., \& Wilson, S. (2007). The black book 'Green Fifty': The top environmentally responsible outsourcing vendors of 2007. (July).

Brundtland, G. (1987). Our common future. Report of the 1987 World Commission on Environment and Development. Oxford: Oxford University Press.

Carter, C. R., \& Easton, P. L. (2011). Sustainable supply chain management: evolution and future directions. International Journal of Physical Distribution \& Logistics Management, 41(1), 46-62. http://dx.doi.org/10.1108/09600031111101420

Carter, C. R., \& Rogers, D. S. (2008). A framework of sustainable supply chain management: moving toward new theory. International Journal of Physical Distribution \& Logistics Management, 38(5), 360-387. http://dx.doi.org/10.1108/09600030810882816

Cole, M. A., Elliott, R. J. R., \& Fredriksson, P. G. (2006). Endogenous Pollution Havens: Does FDI Influence Environmental Regulations? Scandinavian Journal of Economics, 108(1), 157-178. http://dx.doi.org/10.1111/j.1467-9442.2006.00439.x

Cole, M. A., Elliott, R. J. R., \& Okubo, T. (2011). Environmental outsourcing. Kobe University RIEB discussion paper series, 1-40.

Defee, C. C., Esper, T., \& Mollenkopf, D. (2009). Leveraging closed-loop orientation and leadership for environmental sustainability. Supply Chain Management: An International Journal, 14(2), 87-98. http://dx.doi.org/10.1108/13598540910941957

Dou, Y., \& Sarkis, J. (2010). A joint location and outsourcing sustainability analysis for a strategic offshoring decision. International Journal of Production Research, 48(2), 567-592. http://dx.doi.org/10.1080/00207540903175145

Ederington, J., Levinson, A., \& Minier, J. (2005). Footloose and pollution-free. Review of Economics and Statistics, 87(1), 92-99. http://dx.doi.org/10.1162/0034653053327658

Elkington, J. (1994). Towards the suitable corporation: win-win-win business strategies for sustainable development. California Management Review, 36(2), 90-100. http://dx.doi.org/10.2307/41165746

Eskeland, G. S., \& Harrison, A. E. (2003). Moving to greener pastures? Multinationals and the pollution haven $\begin{array}{lllll}\text { hypothesis. Journal of Development } & \text { Economics, } & 70(1), & 1-23 \text {. }\end{array}$ http://dx.doi.org/10.1016/s0304-3878(02)00084-6

Facanha, C., \& Horvath, A. (2005). Environmental Assessment of Logistics Outsourcing. Journal of Management in Engineering, 27(1), 27-37. http://dx.doi.org/10.1061/(ASCE)0742-597X(2005)21:1(27)

Gray, J. V., Roth, A. V., \& Leiblein, M. J. (2011). Quality risk in offshore manufacturing: Evidence from the pharmaceutical industry. Journal of Operations Management, 29(7-8), 737-752. http://dx.doi.org/10.1016/j.jom.2011.06.004

Grossman, G. M., \& Elhanan, H. (2005). Outsourcing in a global economy. Review of Economic Studies, 72 , 135-159. http://dx.doi.org/10.1111/0034-6527.00327

Holcomb, T. R., \& Hitt, M. A. (2007). Toward a model of strategic outsourcing. Journal of Operations Management, 25(2), 464-481. http://dx.doi.org/10.1016/j.jom.2006.05.003

Hollos, D., Blome, C., \& Foerstl, K. (2012). Does sustainable supplier co-operation affect performance? Examining implications for the triple bottom line. International Journal of Production Research, 50(11), 2968-2986. http://dx.doi.org/10.1080/00207543.2011.582184

Hsu, C. W., \& Hu, A. H. (2009). Applying hazardous substance management to supplier selection using analytic network process. Journal of Cleaner Production, 17(2), 255-264. http://dx.doi.org/10.1016/j.jclepro.2008.05.004

Hunt, S. D., \& Davis, D. F. (2008). Grounding supply chain management in resource-advantage theory. Journal of Supply Chain Management, 44(1), 10-21. http://dx.doi.org/10.1111/j.1745-493X.2008.00042.x 
Jain, D. M., \& Khurana, R. (2013). Need for sustainable global business model in software outsourcing The Indian perspective. Business Process Management Journal, 19(1), 54-69. http://dx.doi.org/10.1108/14637151311294868

Kannan, V. R., \& Tan, K. C. (2002). Supplier Selection and Assessment: Their Impact on Business Performance. The Journal of Supply Chain Management, Fall, 11-21. http://dx.doi.org/10.1111/j.1745-493X.2002.tb00139.x

Klassen, R. D., \& Vachon, S. (2003). Collaboration and evaluation in the supply chain: the impact on plant-level environmental investment. Production and Operations Management, 12(3), 336-352. http://dx.doi.org/10.1111/j.1937-5956.2003.tb00207.x

Kroes, J. R., \& Ghosh, S. (2010). Outsourcing congruence with competitive priorities: Impact on supply chain and firm performance. Journal of Operations Management, 28(2), 124-143. http://dx.doi.org/10.1016/j.jom.2009.09.004

Kumar, S., Medina, J., \& Nelson, M. T. (2009). Is the offshore outsourcing landscape for US manufacturers migrating away from China? Supply Chain Management: An International Journal, 14(5), 342-348. http://dx.doi.org/10.1108/13598540910980251

Lacity, M. C., Khan, S. A., \& Willcocks, L. P. (2009). A review of the IT outsourcing literature: Insights for practice. The Journal of Strategic Information Systems, 18(3), 130-146. http://dx.doi.org/10.1016/j.jsis.2009.06.002

Lankford, W. M., \& Parsa, F. (1999). Outsourcing a primer. Management Decision, 37(4), 310-316. http://dx.doi.org/10.1108/00251749910269357

Lee, A. H., Kang, H. Y., Hsu, C. F., \& Hung, H. C. (2009). A green supplier selection model for high-tech industry. Expert Systems with Applications, 36(4), 7917-7927. http://dx.doi.org/10.1016/j.eswa.2008.11.052

Lotspeich, R., \& Chen, A. (1997). Environmental protection in the People's Republic of China. Journal of Contemporary China, 6(14), 33. http://dx.doi.org/10.1080/10670569708724264

Lubin, D. A., \& Esty, D. C. (2010). The sustainability imperative. Harvard business review, 88(5), 42-50.

Min, H., \& Galle, W. P. (1997). Green Purchasing Strategies: Trends and Implications. International Journal of $\begin{array}{llll}\text { Purchasing and } \text { Materials } & \text { Management, } & 33(3), & \text { 10 }\end{array}$ http://dx.doi.org/10.1111/j.1745-493X.1997.tb00026.x

Paulraj, A. (2011). Understanding the relationships between internal resources and capabilities, sustainable supply management and organizational sustainability. Journal of Supply Chain Management, 47(1), 19-37. http://dx.doi.org/10.1111/j.1745-493X.2010.03212.x

Porter, M. E., \& Kramer, M. R. (2006). The link between competitive advantage and corporate social responsibility. Harvard business review, 84(12), 78-92.

Seuring, S., \& Müller, M. (2008). From a literature review to a conceptual framework for sustainable supply chain management. Journal of Cleaner Production, 16(15), 1699-1710. http://dx.doi.org/10.1016/j.jclepro.2008.04.020

Smil, V. (1993). China's environmental crisis: an inquiry into the limits of national development: ME Sharpe.

Social Accountability International. SA8000 Certification. Retrieved 31 Mar, 2014, from http://www.sa-intl.org/index.cfm?fuseaction=Page.viewPage\&pageId=617\&parentID=473

Tracey, M., \& Tan, C. L. (2001). Empirical analysis of supplier selection and involvement, customer satisfaction, and firm performance. Supply Chain Management: An International Journal, 6(4), 174-188. http://dx.doi.org/10.1108/EUM0000000005709

Vonderembse, M. A., \& Tracey, M. (1999). The Impact of Supplier Selection Criteria and Supplier Involvement on Manufacturing Performance. The Journal of Supply Chain Management, Summer, 33-39. http://dx.doi.org/10.1111/j.1745-493X.1999.tb00060.x

Wernerfelt, B. (1984). A Resource-based View of the Firm. Strategic Management Journal, 5, 171-180. http://dx.doi.org/10.1002/smj.4250050207

Williamson, O. E. (1979). Transaction-cost economics, the governance of contractual relations. Journal of Law and Economics, 22(2), 233-261. 
Williamson, O. E. (2008). Outsourcing: transaction cost economics and supply chain management. Journal of Supply Chain Management, 44(2), 5-16. http://dx.doi.org/10.1111/j.1745-493X.2008.00051.x

Zhang, A., \& Huang, G. Q. (2012). Impacts of business environment changes on global manufacturing outsourcing in China. Supply Chain Management: An International Journal, 17(2), 138-151. http://dx.doi.org/10.1108/13598541211212889

Zhu, Q., Sarkis, J., \& Lai, K. H. (2012). Examining the effects of green supply chain management practices and their mediations on performance improvements. International Journal of Production Research, 50(5), 1377-1394. http://dx.doi.org/10.1080/00207543.2011.571937

\section{Copyrights}

Copyright for this article is retained by the author(s), with first publication rights granted to the journal.

This is an open-access article distributed under the terms and conditions of the Creative Commons Attribution license (http://creativecommons.org/licenses/by/3.0/). 